\title{
Effects of NPK fertilizer on growth, drymatter production and yield of eggplant in southwestern Nigeria
}

\author{
${ }^{1}$ Nafiu, Adewale Kehinde, ${ }^{2}$ Togun, Adeniyi. O. ${ }^{3}$ Abiodun, Moses Olabiyi, and ${ }^{1}$ Chude, \\ Vincent Okechukwu. \\ ${ }^{1}$ Agricultural Productivity Enhancement, National Programme for Food Security (NPFS), \\ Federal Ministry of Agriculture and Water Resources, Abuja, Nigeria. \\ ${ }^{2}$ Department of Crop Protection and Environmental Biology, University of Ibadan, Ibadan, \\ Nigeria. \\ ${ }^{3}$ Laboratory of Plant Nutrition, Department of Bioscience and Biotechnology, Kyushu \\ University, Fukuoka, Japan.
}

\begin{abstract}
The growth, dry matter and yield of eggplant under varying levels of NPK 15:15:15 were evaluated in both pot and field trials. Results from the pot trial showed a significant enhancement in fruit yield with increasing fertilizer level up to $200 \mathrm{~kg} / \mathrm{ha}$ while other shoot's characteristics (leaf number, branch number and stem length) were favoured up to $300 \mathrm{~kg} / \mathrm{ha}$. Unexpectedly, a significant branch number increment at $300 \mathrm{~kg} / \mathrm{ha}$ did not lead to a significant yield increase. Field trial's results showed that growth, yield and other shoot's characteristics greatly increased up to $200 \mathrm{kgNPK} / \mathrm{ha}$ application after which there was either insignificant increment or a decline. Increment of dry weight towards maturity suggests that there was no cessation in eggplant growth even when partitioning of assimilates towards fruit development took place. The study concluded that $200 \mathrm{kgNPK} / \mathrm{ha}$ is adequate for optimum growth, dry matter production (pre-anthesis and anthesis stages) and yield in both field and greenhouse conditions.
\end{abstract}

Keywords: NPK fertilizer, Eggplant, Nigeria, Yield, Dry matter, Growth.

\section{INTRODUCTION}

Eggplant (Solanum melongena L.) is grown as one of the important fruit vegetable crops in Nigeria (Thompson and Kelly 1977). It is grown for its fruits which are utilized as vegetables to contribute to the essential nutrients in our diet (Norman, 1974; Langer and Hill, 1976; Siemonsma, 1981).

Fruit yield in eggplant is dependent on a number of factors which include flowering (anthesis), pests and diseases infection, soil nutrient status (soil fertility) and the course of fertilizer application (Huth and Pellmyr, 1977).

Eggplant is also a heavy feeder and occupies the ground for a long period of time, so one or two dressing of fertilizer may be necessary( McCollum, 1980).Its production in south western Nigeria is constrained by the low level of soil fertility, coupled with poor prevailing climatic conditions and this result in low yield of the plant.

Fertilization has been a component of improved cultural practices for most crops since over 95 percent of most arable land of south west Nigeria are under frequent cultivation. Constraints and the problem of soil nutrients of low to medium level of available nutrients have caused yield below potential levels (Adepetu, 1986). The best way of preventing soil from becoming poor is to put back into it what plant has taken out and this can only be achieved by the use of inorganic fertilizer (Roberts and Andrew, 1989). In good soil fertility management programme, proper timing and good fertilization are necessary to maintain high levels of crop production (i.e. yield), (Harper, 1983).

Cooke (1972) reported that the major nutrients required by the crop are Nitrogen $(\mathrm{N})$, Phosphorus $(\mathrm{P})$ and Potassium $(\mathrm{K})$. Inadequate supply of any of these nutrients during crop growth is known to have negative impact on the reproductive capability, growth and yield of the plant (Vine, 1953; Solubo, 1972) and supplementary amount of nutrients can be added to soil inform of inorganic fertilizer to correct inadequate supply of nutrients to the crop (Dirk and Hogarth,1984).

Nitrogen $(\mathrm{N})$ as an element has been identified to be of critical importance to high yield of eggplant during vegetative development, flowering and seed set 
(Hashimoto and Yamamoto, 1970; Lathwell and Evans, 1951; Hashimoto, 1971). While phosphorus $(P)$ influences fruiting habits, hasten maturity, increases disease resistance, improves palatability of fruit, increases protein levels and lower fat content of seeds of eggplant, as well as balancing other plant nutrients (Thorup, 1984; Olson et al, 1971). For potassium (K), its deficiency results in growth restriction and reduction in leaf size. Also, un-even ripening of the fruit can be expected as well as having specific influence on the fruit quality (Roordavan, 1981).

Since most Nigerian eggplant farmers apply mineral fertilizers without considering the optimum level that will minimize production cost, maximize yield, reduce wastage of fertilizer and reduce soil toxicity, this research was undertaken to find out an optimum level of chemical fertilizer NPK 15: 15:15 that can maximize growth, dry matter production and much more importantly, fruit yield of eggplant under the poor climatic and soil conditions of southwestern, Nigeria.

\section{MATERIALS AND METHODS}

The study was carried out as pot and field experiments. The pot and field trials were conducted in 2004/2005 cropping season in southwestern Nigeria at Roof-Top and Crop Garden of Crop Protection and Environmental Biology (CPEB) University of Ibadan (Latitude 0722 'N; longitude 03 58 'E). Prior to planting, soil samples from the site were collected for routine analysis and the result is presented in table 1.

Table1: PRE- PLANTING SOIL ANALYTICAL RESULTS

\begin{tabular}{|l|l|}
\hline SOIL PROPERTIES & VALUES \\
\hline $\mathrm{pH}\left(\mathrm{H}_{2} \mathrm{O}\right)$ & 5.3 \\
\hline$\%$ Sand & 76.0 \\
\hline \%Silt & 16.0 \\
\hline \% Clay & 8.0 \\
\hline Exchangeable $\mathrm{Ca}(\mathrm{Cmol} / \mathrm{kg})$ & 1.70 \\
\hline Exchangeable $\mathrm{Mg}(\mathrm{Cmol} / \mathrm{kg})$ & 1.05 \\
\hline Exchangeable $\mathrm{K}(\mathrm{Cmol} / \mathrm{kg})$ & 0.20 \\
\hline Exchangeable $\mathrm{Na}(\mathrm{Cmol} / \mathrm{kg})$ & 0.41 \\
\hline Exchangeable $\mathrm{H}^{+}(\mathrm{Cmol} / \mathrm{kg})$ & 0.14 \\
\hline $\begin{array}{l}\text { C.E.C ( Cation Exchange } \\
\text { Capacity) }\end{array}$ & 3.50 \\
\hline \%Base & 98.0 \\
\hline \% Carbon & 2.75 \\
\hline \% Total Nitrogen & 0.25 \\
\hline \% Organic matter & 4.78 \\
\hline Available P(ppm) & 5.02 \\
\hline Extractable Zn( ppm) & 2.08 \\
\hline Extractable Fe (ppm) & 1.65 \\
\hline
\end{tabular}

Pot experiment: Seeds of a local cultivar of eggplant (Solanum melongena L.) named "Godogidi" were sown in nursery and later transplanted into pots 2 weeks after planting (WAP) at the rate of one plant per pot. A total of eighty four pots were used arranged in (RCBD) Randomized Complete Block Design with 3 replicates. Each pot contained $4 \mathrm{~kg}$ of soil from the site where the field trial was finally conducted. There were 28 plants per block (i.e. 7 plants per treatment level in a block). The treatment consisted of 4 levels of chemical fertilizer (NPK 15:15:15) applied at 4 (WAP) at the rate of 0,100 , 200 and $300 \mathrm{~kg} / \mathrm{ha}$ NPK. The amount of chemical fertilizer applied for the above rates were calculated as $0,1.3,2.6$ and $3.9 \mathrm{~g} / \mathrm{plot}$ respectively. Weeds and pests were controlled and the crops were maintained to maturity. Data on yield, growth and dry matter production were collected and subjected to 2 ways analysis of variance (ANOVA) and means separated with Least Significant Difference (LSD) at $P=0.05$.

Field experiment: The experimental area of land was cleared and mapped out into plots or units during the rainy season. The whole area of land cultivated for the trial was $21 \mathrm{~m} \times 18.2 \mathrm{~m}$. Each plot size was $4.2 \mathrm{~m}$ by $5.4 \mathrm{~m}$ with $1 \mathrm{~m}$ alleyway between the plots. Seeds of Solanum melongena L. (Godogidi) were sown in the nursery for 35 days before they were transplanted into the field (flat) at $0.9 \mathrm{~m}$ between rows and $0.6 \mathrm{~m}$ within rows to give 504 plants on $382.2 \mathrm{~m}^{2}$ of land. RCB Design with 3 replicates and 4 fertilizer levels served as treatments as in the pot experiment. There were a total of 12 experimental plots. Each plot consisted of 6 rows of 7 plants per row. Data on yield, growth and dry matter production were collected as in the pot experiment.

\section{RESULTS AND DISCUSSION}

PRE-PLANTING SOIL ANALYSIS: The result of the pre-planting soil analysis (to affirm the soil conditions) is presented in Table 1.

POT EXPERIMENT: The results obtained for the pot experiments are presented in Table 2, Figures $1 a, b$, $\mathrm{c}$, and $\mathrm{d}$.

The fruit dry weight increased from OkgNPKha ${ }^{1}$ (3.6g/ plant) to $200 \mathrm{kgNPKha}^{-1}$ (5.5g/plant) and then declined. This indicated that plant treated with 200 $\mathrm{kg} / \mathrm{ha}$ NPK gave the highest fruit weight compared to other levels (Table 2). There were significant differences among the treatment levels in terms of fruit weight. 
At $300 \mathrm{kgNPK} / \mathrm{ha}$, the dry weights of leaf $(3.3 \mathrm{~g})$, stem $(7.8 \mathrm{~g})$, root $(6.4 \mathrm{~g})$ and total $(17.3 \mathrm{~g})$ per plant performed better than in control(Table 2). This was strongly followed by treatment of $200 \mathrm{kgNPK} / \mathrm{ha}$ and
$100 \mathrm{kgNPK} / \mathrm{ha}$ respectively. The lowest was obtained from $0 \mathrm{kgNPKha}^{-1}$. There were significant differences among the treatment levels for all the parts partitioned (Table 2).

Table 2: Effect of NPK fertilizer on Leaf, Stem, Root, Total and Fruit Dry weights of eggplant (Solanum melongena L.) in the pot experiment in South-west Nigeria.

\begin{tabular}{|c|c|c|c|c|c|}
\hline Treatments & $\begin{array}{l}\text { Leaf Dry } \\
\text { wt(g) }\end{array}$ & Stem Dry wt(g) & Root Dry wt(g) & $\begin{array}{l}\text { Total Dry } \\
\text { wt(g) }\end{array}$ & $\begin{array}{l}\text { Fruit Dry wt (yield) } \\
\text { g/plant }\end{array}$ \\
\hline $0 \mathrm{KgNPKha}^{-1}$ & $1.4 \mathrm{C}$ & $3.3 c$ & $2.0 \mathrm{c}$ & $6.5 \mathrm{c}$ & $3.6 \mathrm{~b}$ \\
\hline 100KgNPKha ${ }^{-1}$ & $1.8 \mathrm{bc}$ & $5.0 \mathrm{~b}$ & $2.9 \mathrm{bc}$ & $9.7 b$ & $4.6 a$ \\
\hline $200 \mathrm{KgNPKha}^{-1}$ & $3.3 a$ & $7.2 \mathrm{a}$ & $4.3 b$ & $14.8 \mathrm{a}$ & $5.5 a$ \\
\hline $300 \mathrm{KgNPKha}^{-1}$ & $3.3 a$ & $7.8 a$ & $6.4 a$ & $17.3 a$ & $3.5 b$ \\
\hline LSD(0.05) & 0.63 & 0.79 & 1.92 & 2.95 & 1.52 \\
\hline \multirow[t]{2}{*}{ S.E. } & 0.24 & 0.34 & 0.79 & 1.22 & 0.62 \\
\hline & $\mathrm{s}$ & $\mathrm{s}$ & $\mathrm{s}$ & $\mathrm{s}$ & $\mathrm{s}$ \\
\hline
\end{tabular}

The number of leaves per plant increased gradually from 7-11WAT and then declined till plant maturity in all the treatments. $300 \mathrm{kgNPKha}^{-1}$ had the highest number of leaves per plant compare to all other treatment levels and control. There were significant differences between the number of leaves, for all the levels of treatment at 9, 11, and 13 WAT except 7 WAT (Fig 1a). recorded in $300 \mathrm{~kg} \mathrm{NPKha}^{-1}$ at 9-11 WAT and even at plant maturity.(fig 1b). This was strongly followed by application 100kgNPK/ha at 9-11WAT (Fig1b) . An increment in the number of branches did not lead to increased fruit production as might be expected at this level. This might be due to the fact that other shoot characteristics were favoured in growth at the detriment of fruit production.

All treated plants performed better than the control in terms of number of branches and the highest was

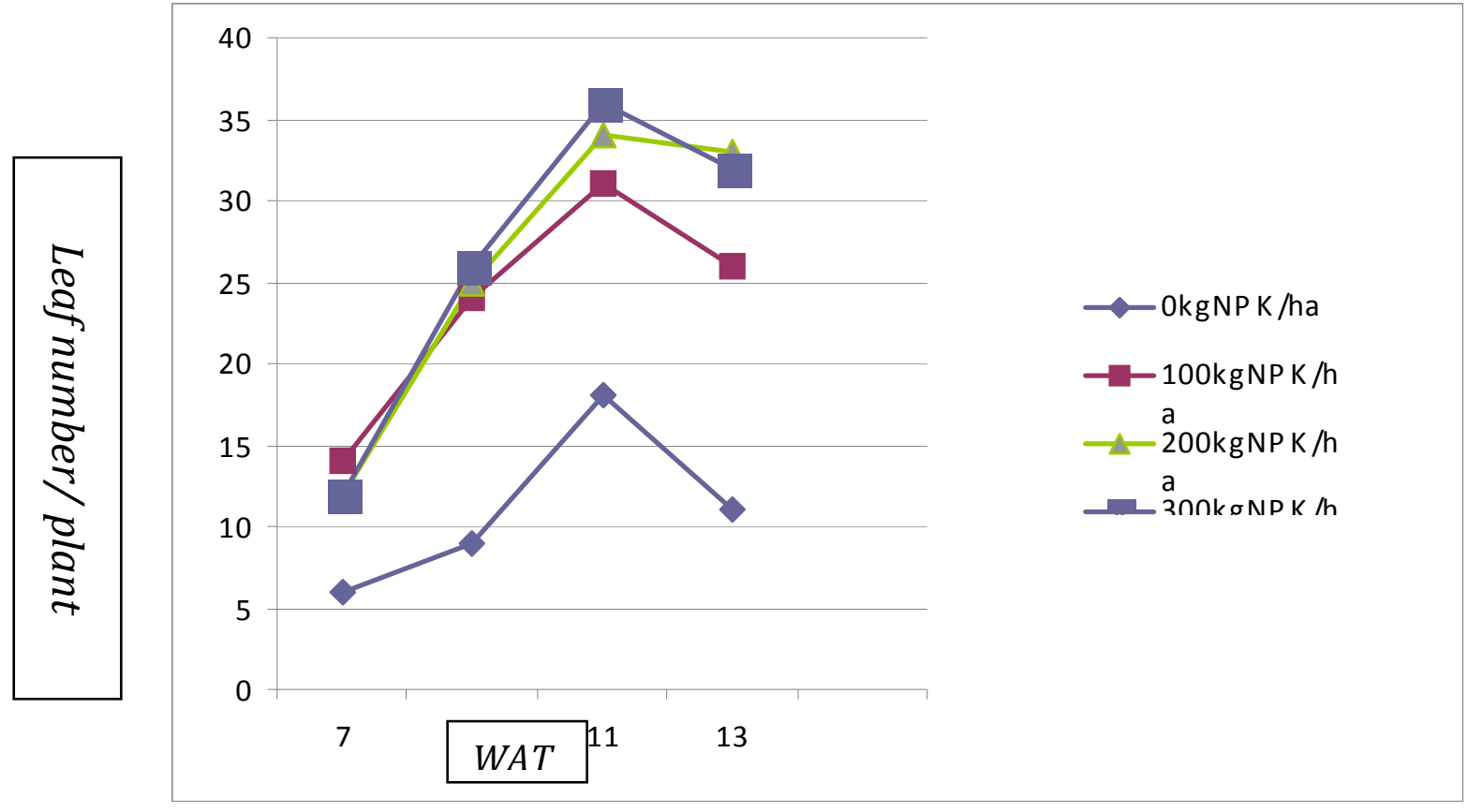

Fig1a: Effect of NPK on Number of leaves of eggplant in pot experiment. 
Agric. Biol. J. N. Am., 2011, 2(7): 1117-1125
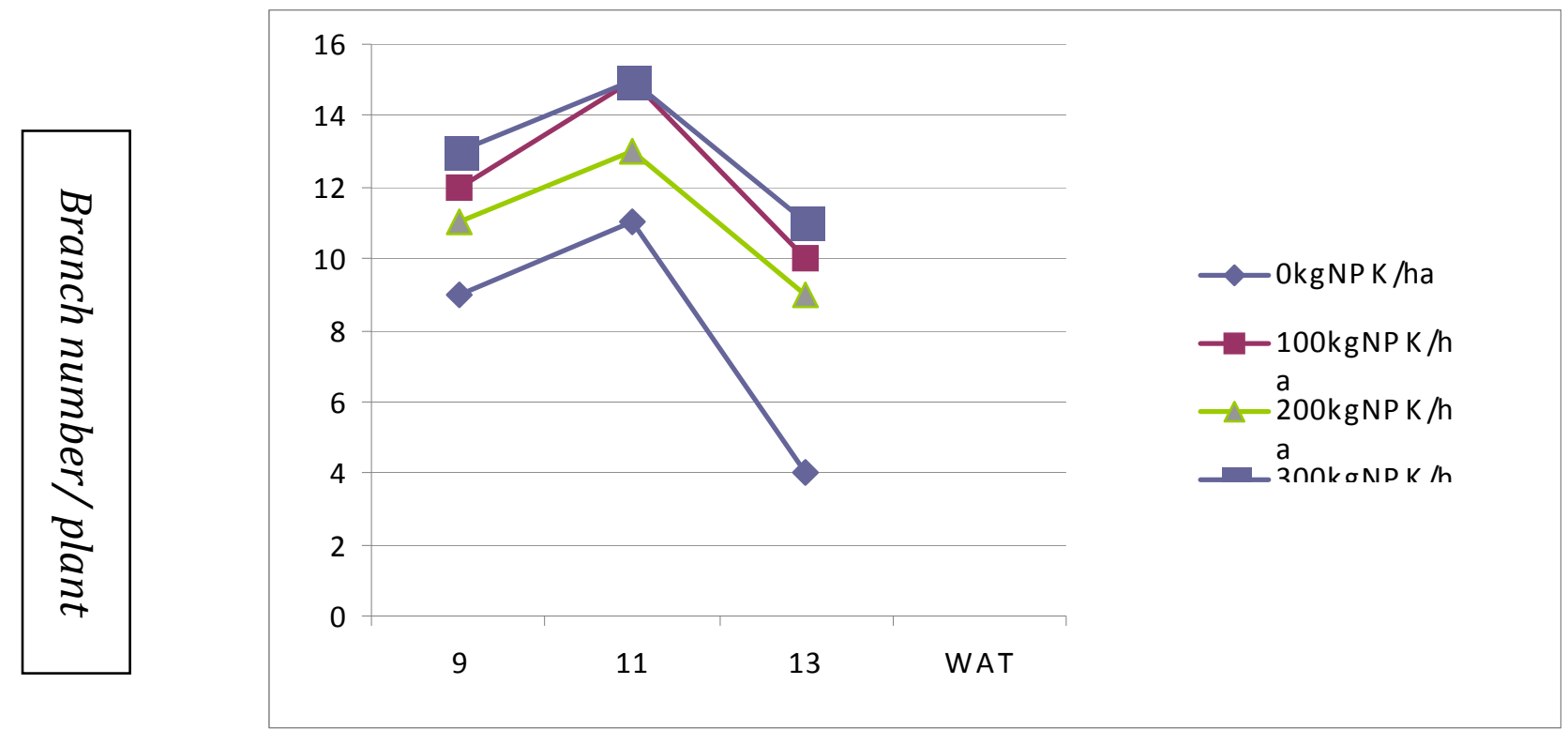

Fig1b: Effect of NPK on Number of branches of eggplant in pot experiment.

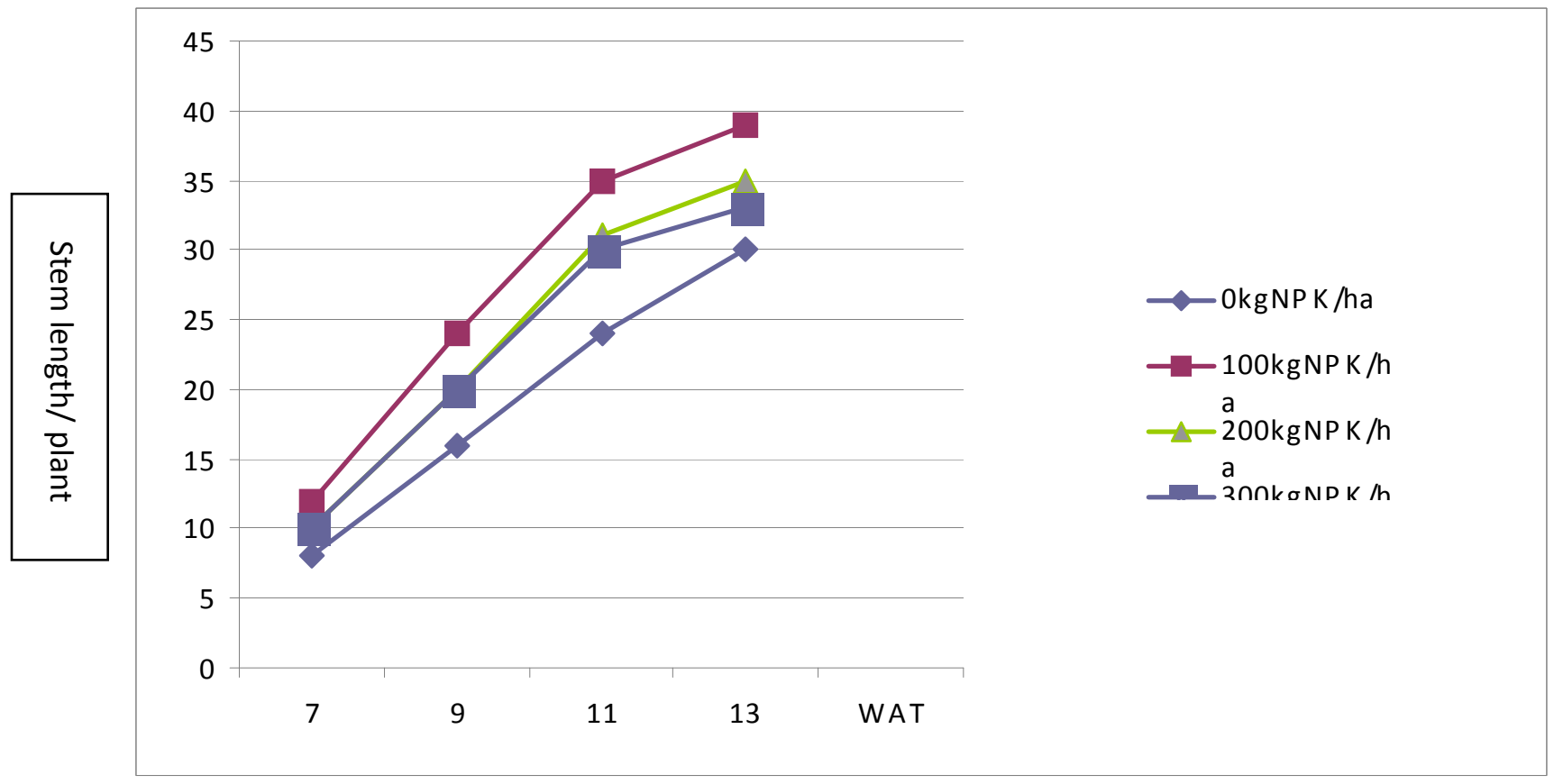

Fig 1c: Effect of NPK on stem length of eggplant in pot experiment. 
Agric. Biol. J. N. Am., 2011, 2(7): 1117-1125

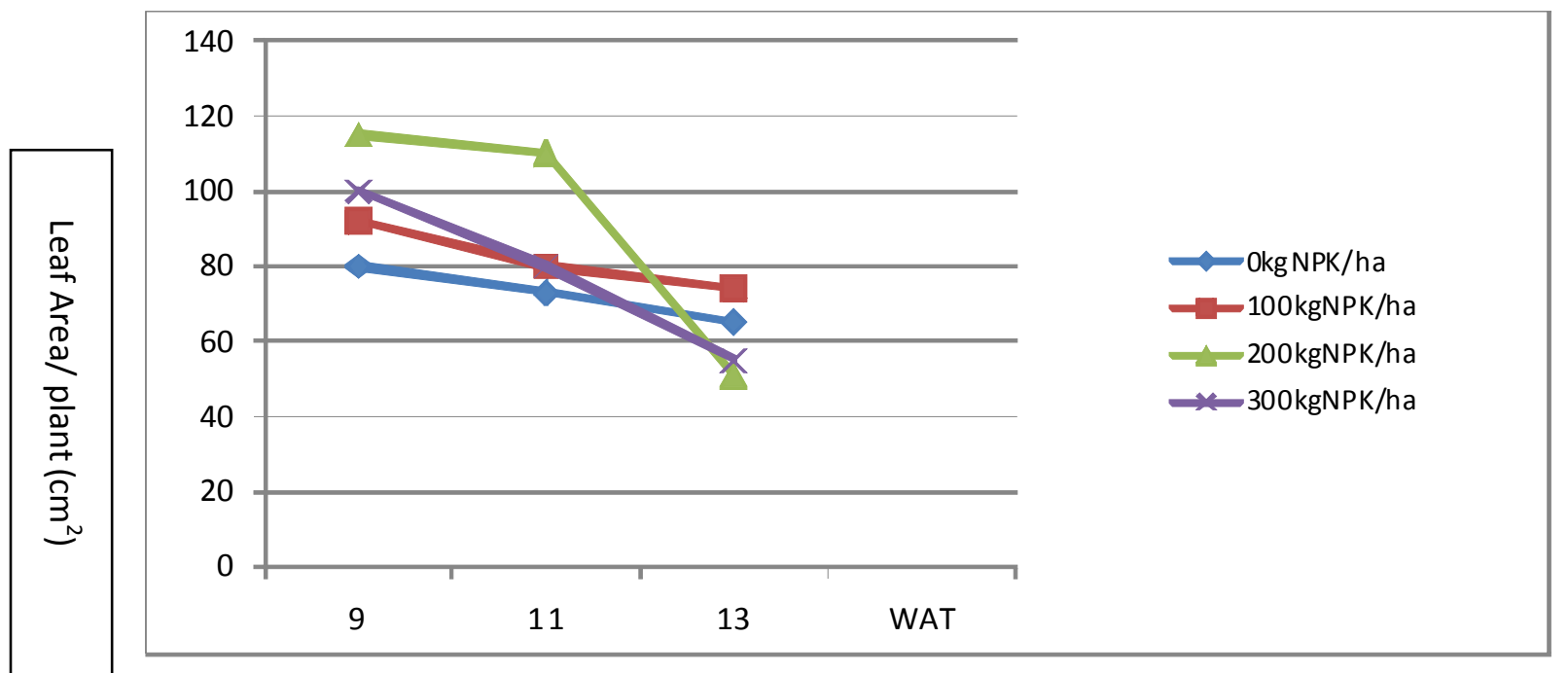

Fig 1d: Effect of NPK on leaf area $\left(\mathrm{cm}^{2}\right)$ of eggplant in pot experiment

.The stem length for all treatments increased rapidly at $7-13$ WAT (up to plant maturity). $100 \mathrm{kgNPKha}^{-1}$ had longer stem length than the control and other treated plant between 9-13 WAT (up to plant maturity) (fig 1c).There was no significant difference between the treatment. The lowest was obtained in application of $0 \mathrm{kgNPKha}^{-1}$.

The leaf area for all the treated plants performed better than the control. Highest leaf area was obtained in application of $200 \mathrm{~kg} \mathrm{NPKha}^{-1}$ and lowest Table 3: Effect of NPK (15:15:15) fertilizer on Leaf, Stem, Root and Total dry weights of eggplant (Solanum melongena $\mathrm{L}$ ) at pre-anthesis stage on the field.

\begin{tabular}{|l|l|l|l|l|}
\hline Treatments & Leaf Dry wt(g) & Stem Dry wt(g) & Root Dry wt(g) & Total Dry wt(g) \\
\hline $\mathbf{0 ~ K g N P K h a ~}^{-1}$ & 0.27 & 0.08 & 0.07 & 0.42 \\
\hline 100KgNPKha $^{-1}$ & 0.42 & 0.10 & 0.11 & 0.63 \\
\hline 200KgNPKha $^{-1}$ & 0.70 & 0.13 & 0.15 & 0.98 \\
\hline 300KgNPKha & -1 \\
\hline LSD(0.05) & 0.38 & 0.12 & 0.12 & 0.63 \\
\hline S.E. & 2.11 & 0.05 & 0.07 & 0.49 \\
\hline & 0.86 & 0.02 & 0.03 & 0.20 \\
\hline & $\mathrm{NS}$ & $\mathrm{NS}$ & $\mathrm{NS}$ & $\mathrm{NS}$ \\
\hline
\end{tabular}

Table 4: Effect of NPK (15:15:15) fertilizer on leaf, stem, root and total dry weights of eggplant (Solanum melongena L) at anthesis stage on the field.

\begin{tabular}{|l|l|l|l|l|}
\hline Treatments & Leaf Dry wt(g) & Stem Dry wt(g) & Root Dry wt(g) & Total Dry wt(g) \\
\hline 0 KgNPKha $^{-1}$ & 1.37 & 0.27 & 0.54 & 2.18 \\
\hline 100KgNPKha $^{-1}$ & 1.69 & 0.23 & 0.51 & 2.42 \\
\hline 200KgNPKha $^{-1}$ & 3.63 & 0.51 & 0.75 & 4.62 \\
\hline 300KgNPKha & -1 \\
\hline S.E. & 0.77 & 0.09 & 0.20 & 1.05 \\
\hline & 0.19 & 0.07 & 0.20 & 0.95 \\
\hline & NS & NS & NS & NS \\
\hline
\end{tabular}


Agric. Biol. J. N. Am., 2011, 2(7): 1117-1125

Table 5: Effect of NPK (15:15:15)fertilizer on dry weights of Leaf, Stem , Root and Total, Fruit Fresh weight, Total number of fruits and Total yield of Eggplant (Solanum melongena $\mathrm{L}$ ) on the field in Southwest Nigeria.

\begin{tabular}{|c|c|c|c|c|c|c|c|}
\hline Treatments & $\begin{array}{l}\text { Leaf } \\
\text { Dry } \\
\text { wt.(g) }\end{array}$ & $\begin{array}{l}\text { Stem Dry } \\
\text { wt.(g) }\end{array}$ & $\begin{array}{l}\text { Root Dry } \\
\text { wt.(g) }\end{array}$ & $\begin{array}{l}\text { Total Dry } \\
\text { wt.(g) }\end{array}$ & $\begin{array}{l}\text { Fruit weight } \\
\text { ( g/plant) }\end{array}$ & $\begin{array}{l}\text { Total no of } \\
\text { matured } \\
\text { fruits }\end{array}$ & $\begin{array}{l}\text { Total } \\
\text { yield(t/ha) }\end{array}$ \\
\hline $0 \mathrm{KgNPKha}^{-1}$ & 54.9 & 23.0 & 18.5 & 99.9 & 6.9 & 3.7 & 2.3 \\
\hline $100 \mathrm{KgNPKha}$ & 81.0 & 57.2 & 16.6 & 288.4 & 413.5 & 31.0 & 19.4 \\
\hline $200 \mathrm{KgNPKha}^{-}$ & 90.7 & 69.2 & 18.9 & 366.3 & 582.5 & 57.0 & 37.0 \\
\hline${ }_{1}^{300 K g N P K h a}$ & 118.2 & 73.1 & 24.4 & 367.3 & 507.5 & 28.7 & 27.4 \\
\hline S.E + & 4.0 & 13.0 & 4.4 & 212.1 & 219.7 & 208.7 & 9.1 \\
\hline & NS & NS & NS & NS & NS & NS & NS \\
\hline
\end{tabular}

The application of $200 \mathrm{kgNPKha}^{-1}$ gave the highest fresh fruit weight $(582.5 \mathrm{~g} / \mathrm{plant})$, total number of matured fruits (57.0) and total yield (37.0 t/ha) when compared to the other treatment levels. While the lowest value was obtained at $0 \mathrm{kgNPKha}^{-1}$ plots in all the parameters mentioned above (Table 5). Meanwhile, there were no significant differences between the fertilized plants and control in respect to number of matured fruits per plant, fruit weight, total number of matured fruits and total yield (Table 5).
The result of effect of NPK fertilizer on growth of eggplant in the field is shown in figure 2. The stem length for all the treatments increased rapidly from 717 WAT (plant maturity). $200 \mathrm{~kg} \mathrm{NPKha}^{-1}$ treatment had longer stem length than other treated plants and control between 7-17 WAT. There were significant differences among the treatments at 7WAT while there was no significant difference between 9-17 WAT (Fig 2a).

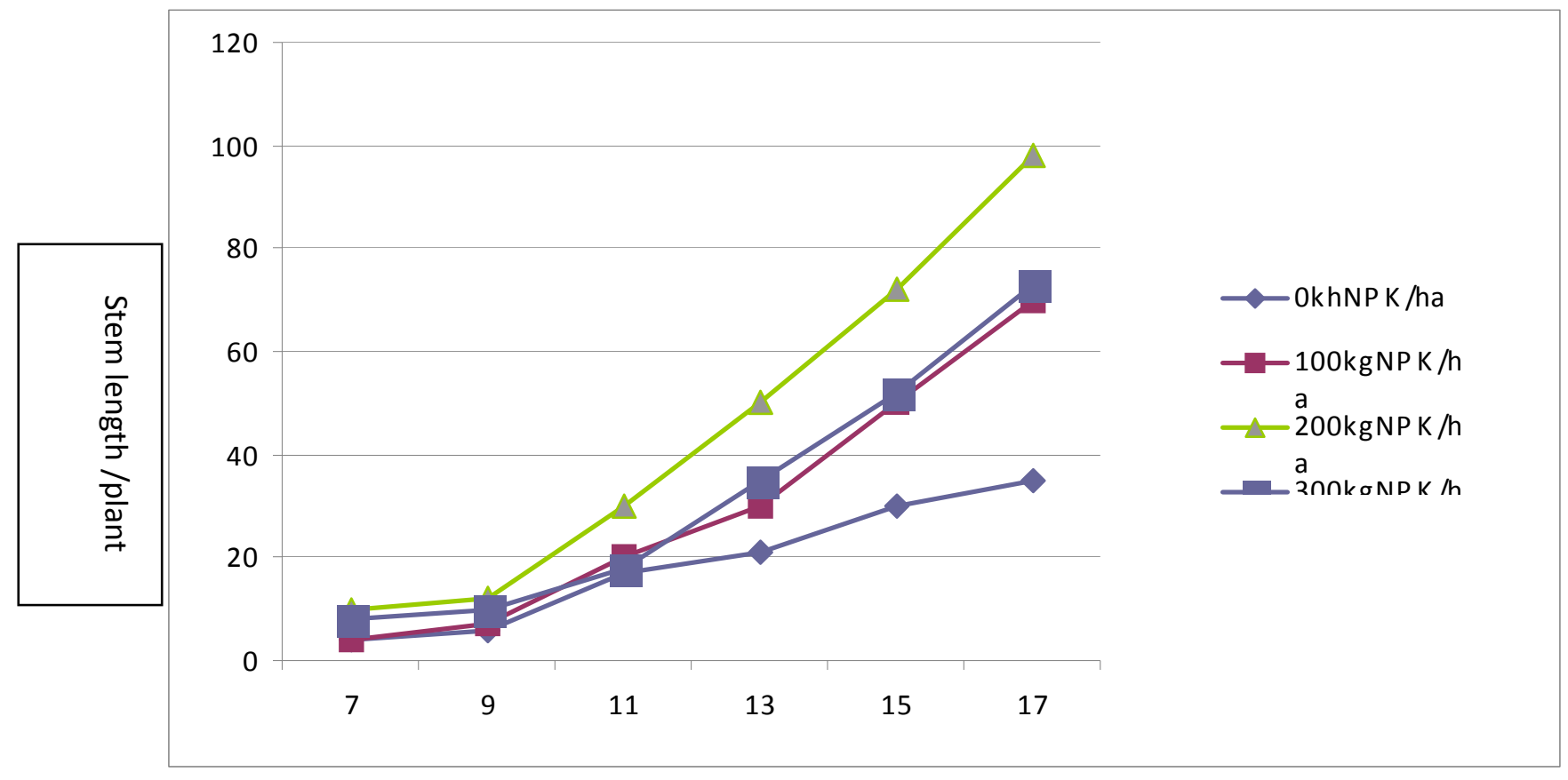

Fig 2a: Effect of NPK fertilizer on stem length $(\mathrm{cm})$ of eggplant in field experiment 
All treated plants performed better than the $0 \mathrm{~kg}$ NPKha ${ }^{-1}$ in terms of number of branches per plant and the highest value was recorded in the application of $200 \mathrm{~kg} \mathrm{NPKha}^{-1}$ from 9-17 WAT, and lowest in 0kgNPKha ${ }^{-1}$. The number of branches per plant increased rapidly from 9-15 WAT then declined to maturity. No significant difference was observed among the treated plants and control at 11, 13 and17 WAT, but there were significant differences among the levels at 9WAT and 15 WAT (Fig 2b).

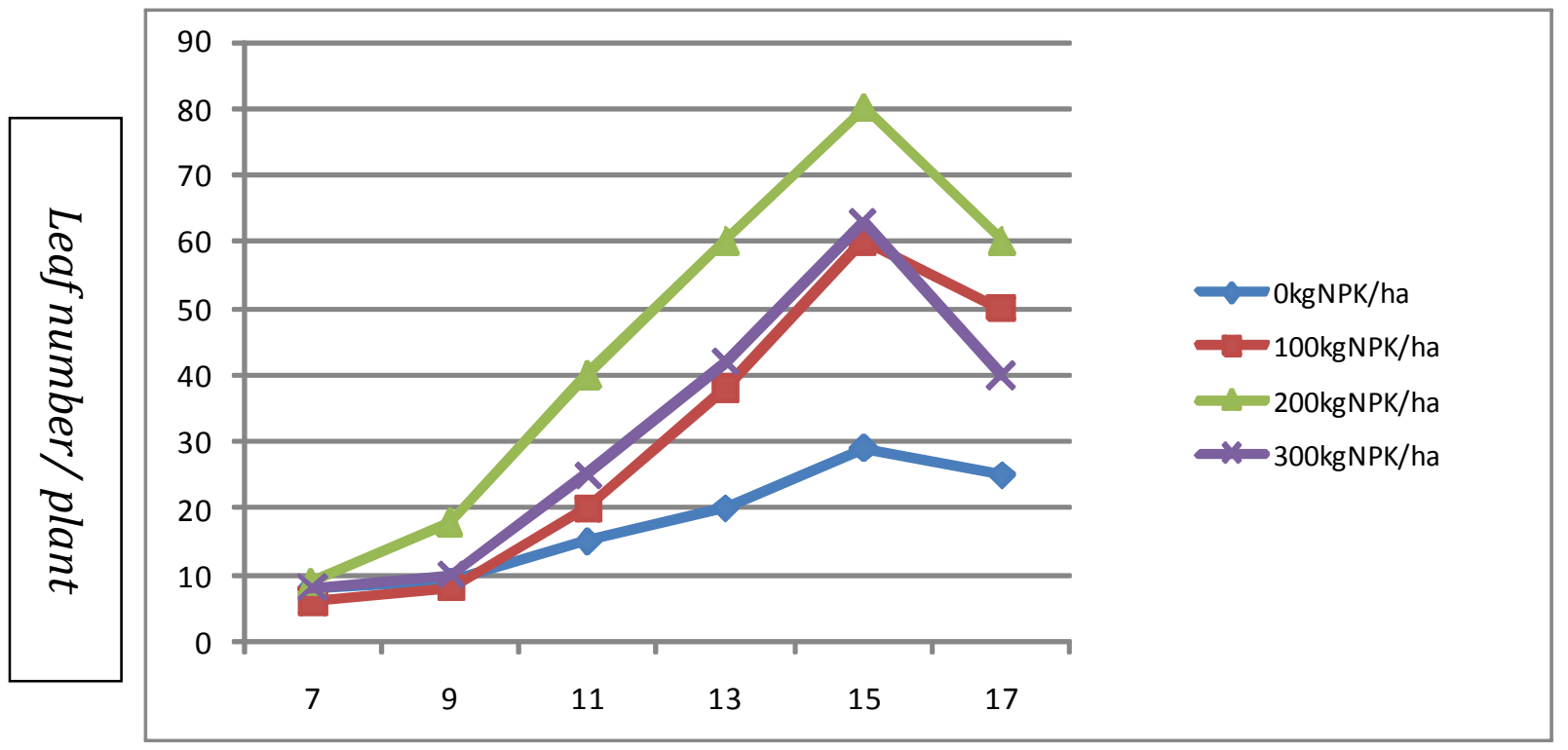

Fig 2b: Effect of NPK fertilizer on number of leaves of eggplant in field experiment

The highest number of leaves per plant was obtained in application of $200 \mathrm{~kg} \mathrm{NPKha}^{-1}$ and followed closely by $300 \mathrm{kgNPKha}^{-1}$ and $100 \mathrm{kgNPKha}^{-1}$ respectively (fig 2c). At plant maturity, the lowest value was obtained in $0 \mathrm{~kg}$ NPKha-1 and there was no significant difference among treatments between 9-13 WAT except at 7WAT (fig 2c).

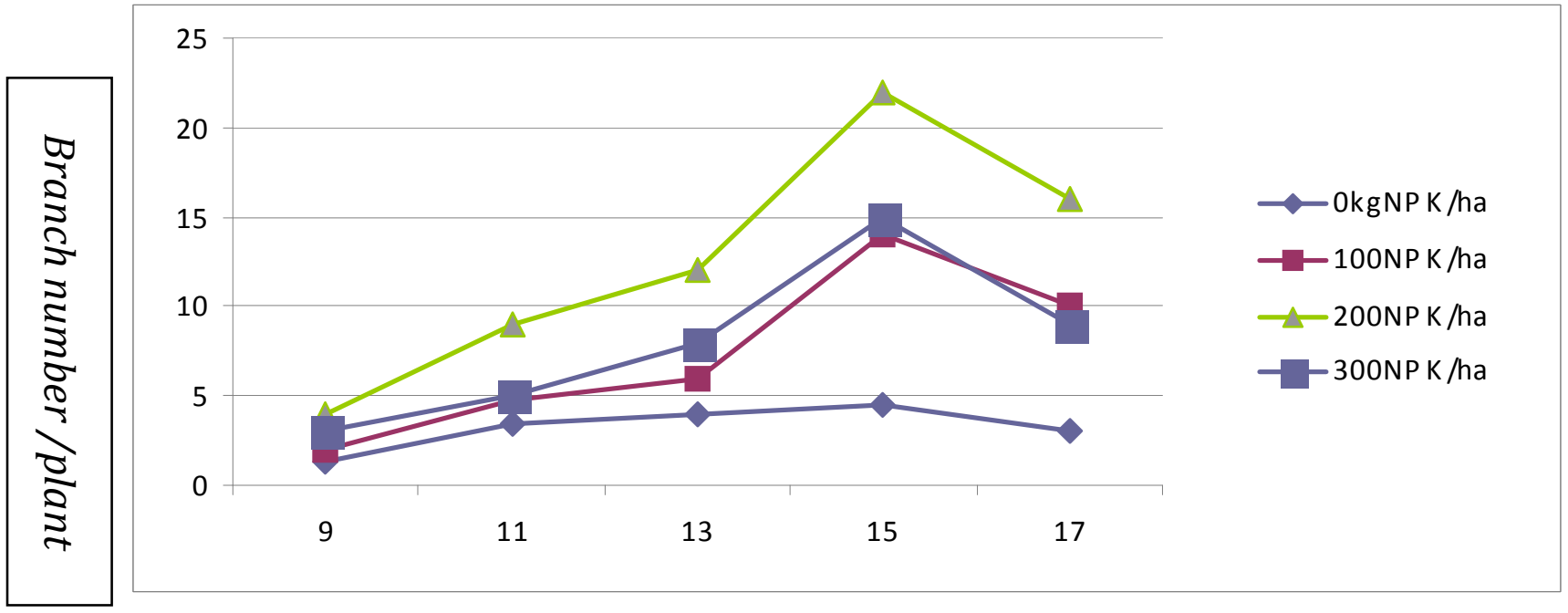

Fig 2c: Effect of NPK fertilizer on number of branches of eggplant in field experiment 
Application of $200 \mathrm{~kg} \mathrm{NPKha}^{-1}$ performed better in terms of leaf area compared to other treated plants and control (i.e. 7-17 WAT). This was strongly followed by $300 \mathrm{kgNPKha}^{-1}$ between 9 -17WAT and lowest value obtained in $0 \mathrm{kgNPKha}^{-1}$. Also, there was a rapid increase in the leaf area from 7-13 WAT before declining till maturity. There were significant differences among the treatments at 13WAT and 17WAT (fig 2d).

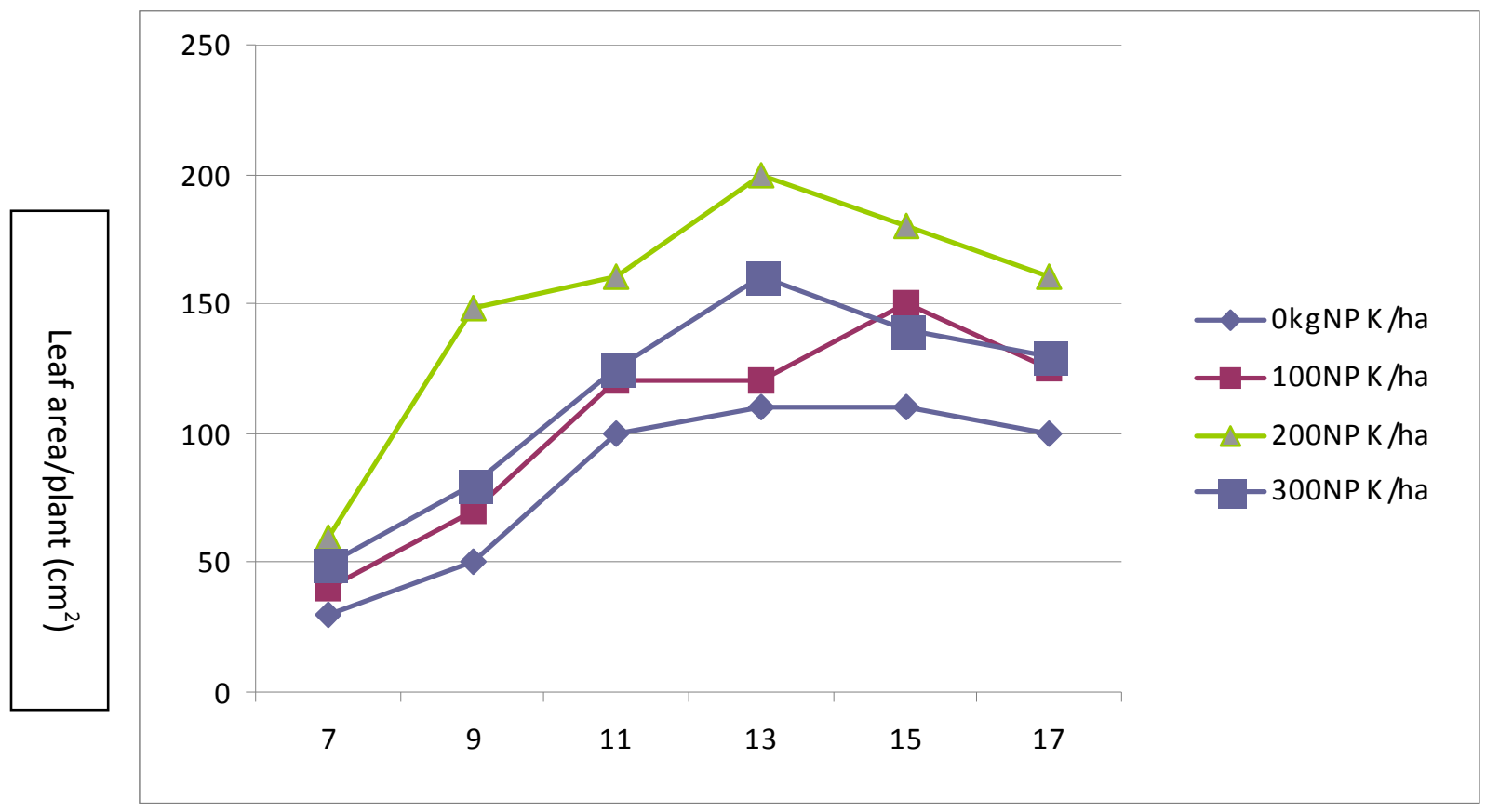

Fig 2d: Effect of NPK fertilizer on Leaf Area $\left(\mathrm{cm}^{2}\right)$ of eggplant in field experiment.

Dry weights of the various part of plant were greatly enhanced by NPK application. The dry weights continued to increase up to plant maturity.

The dry weights of leaf, stem, root and Total dry weight increased progressively with age of plant. Although dry weights were slow between the preanthesis and anthesis stages of the plant, it increased sharply thereafter up to plant maturity (Tables 4and 5)

Pre-anthesis and Anthesis stages: The leaf, stem, root and total dry weights per plant increased from applications of $0-200 \mathrm{kgNPkha}^{-1}$ and then declined. There was no significant difference among the treatment levels and the highest dry weight of leaf $(0.70 \mathrm{~g})$, stem $(0.13 \mathrm{~g})$, root $(0.15 \mathrm{~g})$ and Total dry weight per plant $(0.98 \mathrm{~g})$ was obtained in plants with $200 \mathrm{kgNPKha}^{-1}$ applications and lowest with OkgNPKha ${ }^{-1}$ application (Table 3).

The highest dry weights for leaf $(3.6 \mathrm{~g})$, stem $(0.51 \mathrm{~g})$, root $(0.75 \mathrm{~g})$ and Total weight $(4.62 \mathrm{~g})$ per plant was obtained in plants with $200 \mathrm{kgNPKha}^{-1}$ and lowest with
OkgNPKha ${ }^{-1}$ (Table 4);and there was no significant difference among the treatment levels.

Plant Maturity: Plants with application of $300 \mathrm{~kg}$ NPK $\mathrm{ha}^{-1}$ had the highest value for leaf(118.2g), stem(73.1g), root (24.4g) and total dry weights $(367.3 \mathrm{~g})$ and lowest were obtained from OkgNPK-ha ${ }^{-1}$ (Table 5). There was no significant difference among the treated plants and control plants.

However, application of $200 \mathrm{kgNPKha}^{-1}$ gave the highest value for fruit fresh weight per plant $(582.5 \mathrm{~g})$, total number of matured fruits (57.0) and total yield(37t/ha) .There was no significant difference among the treated plants and control plants(Table 5).

\section{CONCLUSION}

Growth, yield and dry matter production in the potted plants were enhanced positively during the course of study and application of $200 \mathrm{KgNPKha}^{-1}$ seems adequate for optimum fruit production and leaf 
area in the pot experiment, while $300 \mathrm{kgNPKha}^{-1}$ favoured the dry matter production and growth.

Similarly, application of NPK 15:15:15 fertilizer at the rate of $200 \mathrm{kgNPKha}^{-1}$ to eggplants on the field showed that under prevailing climatic and field conditions with good management practices, the growth, dry matter (pre anthesis and anthesis stages) and yield of eggplant can be greatly improved.

Conclusively, under the prevailing poor climatic and soil conditions, fertilization at $200 \mathrm{Kg}$ NPKha ${ }^{1}(15: 15: 15)$ is adequate for optimum growth, dry matter production and stable yield of eggplant (Solanun melongena L.). However, further studies may be needed to conclude whether this level of application is capable of minimizing disease expression while keeping the yields as high as possible.

\section{REFERENCES}

Adepetu, J. A (1986). Soil fertility and fertilizer requirements in Oyo, Ogun and Ondo States, FDALR, Federal Ministry of Agriculture and Water Resources, (Publ) Lagos.

Cobley, L. S and Steel, M.W (1976). An Introduction to the Botany of Tropical Crops. London: Longman.

Cooke, G. W (1972). Fertilizer for maximum yield. Great Britain: Granada Publishing Limited. pp. 465.

Dirk, A. T and Hargarty, M (eds.) (1984). Soil and Plant Analysis. Guide for Agricultural Laboratory Directors and Technologists in Tropical Region, pp. 147.

Harper, F (1983). Principles of Arable Crop Production. Granada Publishing Ltd. Pp. 336.

Hashimoto, K and Yamamoto, T (1970). Studies on the cool Injury in beam plant 11 . Effect of Time and Period of $\mathrm{N}_{2}$ application on the soybean treated with low temperature before flowering. Crop science society of Japan Proceeding 39:164-170.

Hashimoto, K (1971). The significance of combined and symbolically fixed nitrogen on soybean at successive stages of growth. Hokkaido Natural Agricultural Expatal Station Research bulletin, 99:17-29.
Huth, C. J and Pellmyer, D (1977). Nutrient requirements of solanaceous vegetable crops. Indian journal of agricultural sciences 58:668-672.

Langer, R. A and Hill, G. D (1976). Agricultural Plants. London: Cambridge University Press. pp. 282.

Lathwell, D. J and Evans, C. E (1951). Nitrogen uptake from solution by soybeans of successive stages of Growth. Agronomy Journal 48: 264-270.

Mc Collum, J. P (1980). Producing Vegetable Crops. Interstate printers and publishers Inc. pp. $518-522$.

Norman, J. C (1974). Eggplant production in Ghana. Ghana farmer. Xviii (1 and 3): 25-27.

Olson, R. A., Army, T. J., Hanway, JU. U and KImer, V. J (1971). Fertilizer Technology and use. $2^{\text {nd }}$ Eds. Soil Science society of America, Inc.

Robert, K. M and Andrew, J.W (1989). An Introduction to crop physiology. New York: Longman scientific and technical, Willey, $340 \mathrm{pp}$.

Roordavan, J. P and Smide, K. W (1981). Nutritional Disorder in Glass House Tomatoes, Cucumber and Lettuce. Centre for Agr. Publishing and Documentation Wageningen Pg. 121-15, 35.

Siemonsma, J. S (1981). A survey of indigenous vegetables in Ivory Coast Proc. $6^{\text {th }}$ African Symposium on Horticultural crops, Ibadan, Nigeria.

Solubo, R. A (1972). Studies on white yam (Discorea rotundata) II. Changes in Nutrient content with Age. Experimental agriculture 8: 107-115.

Thompson, H. C and Kelly, C. W (1977). Vegetable Crops. , New York: McGraw Hill Book company. Pp.50.

Thorup, R. M (1984). Ortho Agronomy Handbook: A practical guide to soil fertility and Fertilizer Use. Fertilizer Division Chevron Chemical company, pg. 115-117, 123-129-130.

Vine, $\mathrm{H}$ (1953). Experiments on the Maintenance of soil Fertility in Ibadan, Nigeria, Emp. J. of Expt'l Agric 21: 65-71. 